\title{
Museum Mulawarman sebagai Pusat Konservasi Warisan Budaya
}

\author{
Rae Larasati ${ }^{1}$, Jamil ${ }^{2}$, Marwiah Johansyah ${ }^{3}$ \\ ${ }^{1}$ Mahasiswa Program Konsentrasi Pendidikan Sejarah Universitas Mulawarman \\ 2Dosen Program Konsentrasi Pendidikan Sejarah Universitas Mulawarman \\ ${ }^{3}$ Dosen Program Konsentrasi Pendidikan Sejarah Universitas Mulawarman
}

2jamil_7378sar@yahoo.com

\begin{abstract}
The purpose of this paper is to determine the values of the Hindu-Buddhist culture, which is in the Museum of Mulawarman Tenggarong, Kutai Kartanegara Regency. Based on the findings and discussion shows that cultural values that are in the Museum of Mulawarman are religious, historical, cultural values and social values. The Government's efforts to preserve the cultural values of Hinduism-Buddhism is divided into three: protection, care, and adhering to the rules.
\end{abstract}

Keywords: Mulawarman Museum, values, culture.

\begin{abstract}
ABSTRAK
Tujuan dari tulisan ini adalah untuk menentukan nilai-nilai budaya Hindu-Buddha, yang ada di Museum Mulawarman Tenggarong, Kabupaten Kutai Kartanegara. Berdasarkan hasil temuan dan pembahasan menunjukkan bahwa nilai-nilai budaya yang ada di dalam Museum Mulawarman adalah nilai religius, nilai sejarah, nilai budaya dan nilai-nilai sosial. Usaha-usaha pemerintah untuk melestarikan nilai-nilai budaya Hindu-Buddha dibagi menjadi tiga: perlindungan, perawatan, dan menaati aturan.
\end{abstract}

Kata Kunci: Museum Mulawarman, nilai, budaya.

\section{PENDAHULUAN}

Wilayah Indonesia terdiri atas pulau besar dan kecil yang dihubungkan oleh selat dan laut, hal ini menyebabkan sarana pelayaran merupakan lalu lintas utama penghubung antarpulau. Pelayaran ini dilakukan dalam rangka mendorong aktivitas perdagangan. Pelayaran dan perdagangan yang dilakukan oleh kerajaan-kerajaan di Indonesia bukan hanya dalam wilayah Indonesia saja, tetapi telah jauh sampai ke luar wilayah Indonesia.

Melalui hubungan perdagangan, berkembanglah kebudayaan-kebudayaan yang dibawa oleh para pedagang di Indonesia. Hubungan perdagangan antara Indonesia dan India menyebabkan agama Hindu dan Buddha tersebar di Indonesia serta dianut oleh raja-raja dan para bangsawan. Dari lingkungan raja dan bangsawan itulah agama HinduBuddha tersebar ke lingkungan rakyat biasa.

Filosofi pelestarian didasarkan pada kecenderungan manusia untuk melestarikan nilai-nilai budaya pada masa lalu, namun hal itu memiliki arti penting bagi generasi selanjutnya. Akan tetapi, tindakan pelestarian makin 
menjadi kabur jika dihadapkan pada kenyataan yang sebenarnya. Tindakan pelestarian yang dimaksudkan adalah bagaimana menjaga karya seni sebagai kesaksian sejarah, namun sering berbenturan dengan kepentingan lain, khususnya dalam kegiatan pembangunan.

Pendapat seorang ahli sosiologi, Parsons dan Kroeber (Koentjaraningrat, 1981 : 186) pernah menganjurkan untuk membedakan secara tajam "wujud kebudayaan sebagai suatu sistem dari ide-ide dan konsep-konsep dari wujud kebudayaan sebagai suatu rangkaian tindakan dan aktivitas manusia yang berpola". Maka, serupa dengan Honigmann (Koentjaraningrat, 1981 : 186) membedakan bahwa "adanya tiga gejala kebudayaan, yaitu ideas, activities, artifacts", Honigmann berpendirian bahwa kebudayaan itu ada tiga wujudnya, yaitu (1) wujud kebudayaan sebagai suatu kompleks dari ide-ide, gagasan, nilai-nilai, norma-norma, peraturan dan sebagainya, (2) wujud kebudayaan sebagai suatu kompleks aktivitas serta tindakkan berpola dari manusia dalam masyarakat, dan (3) wujud kebudayaan sebagai benda-benda hasil karya manusia.

Wujud pertama adalah wujud ideal dari kebudayaan. Sifatnya abstrak, tidak dapat diraba atau difoto. Lokasinya ada di dalam kepala-kepala, atau dengan perkataan lain, dalam alam pikiran warga masyarakat di mana kebudayaan bersangkutan itu hidup. Kalau warga masyarakat tadi menyatakan gagasan mereka dalam tulisan, maka lokasi dari kebudayaan ideal sering berada dalam karangan dan buku-buku hasil karya para penulis warga masyarakat yang bersangkutan.

Ide-ide dan gagasan-gagasan manusia banyak yang hidup bersama dalam suatu masyarakat, memberi jiwa pada masyarakat itu. Gagasan-gagasan itu tidak berada lepas satu dari yang lain, melainkan selalu berkaitan menjadi suatu sistem. Para ahli antropolgi dan sosiologi menyebut sistem ini sistem budaya, atau cultural system. Dalam bahasa Indonesia tedapat juga istilah lain yang sangat tepat untuk menyebut wujud ideal dari kebudayaan ini, yaitu adat, atau adat-istiadat untuk bentuk jamaknya.

Wujud kedua dari kebudayaan yang disebut sistem sosial atau social system, mengenai tindakkan berpola dari manusia itu sendiri. Sistem sosial ini terdiri dari aktivitas-aktivitas manusiamanusia yang berinteraksi, berhubungan, serta bergaul satu sama lain dari detik ke detik, dari hari ke hari, dari tahun ke tahun, selalu menurut polapola tertentu yang berdasarkan adat tata kelakuan. Sebagai rangkaian aktivitas manusia-manusia dalam suatu masyarakat, sistem sosial itu bersifat 
konkret, terjadi di sekeliling kita seharihari, bisa diobservasi, difoto, dan didokumentasi.

Wujud ketiga dari kebudayaan disebut kebudayaan fisik, dan tak memerlukan banyak penjelasan. Karena berupa seluruh total dari hasil fisik dari aktivitas, perbuatan, dan karya semua manusia dalam masyarakat, maka sifatnya paling konkret dan berupa benda-benda atau hal-hal yang dapat diraba, dilihat dan difoto.

Ada benda-benda yang sangat besar seperti pabrik baja, benda-benda yang amat kompleks dan canggih seperti komputer yang berkapasitas tinggi, benda-benda yang besar dan bergerak, suatu kapal tangki minyak, bangunan hasil seni arsitek seperti suatu candi yang indah, rumah adat, benda-benda kecil seperti kain batik, atau yang lebih kecil lagi, yaitu kancing baju.

Melalui hubungan perdagangan, berkembanglah kebudayaan-kebudayaan yang dibawa oleh para pedagang di Indonesia. Hubungan perdagangan antara Indonesia dan India membawa agama Hindu dan Buddha tersebar di Indonesia serta dianut oleh raja-raja dan para bangsawan. Dari lingkungan raja dan bangsawan itulah agama HinduBuddha tersebar ke lingkungan rakyat biasa.

Pertumbuhan

kebudayaan masyarakat Indonesia sangat dipengaruhi oleh kebudayaan Hindu dan Buddha dari India. Dalam proses akulturasi tersebut, masyarakat Indonesialah yang banyak berperan aktif. Kenyataan ini dapat kita lihat dari corak peninggalan kebudayaan Hindu dan Buddha di Indonesia. Peninggalanpeninggalan itu tidak sepenuhnya hasil jiplakan langsung dari India, melainkan masyarakat Indonesia sendiri, ketika menerima pengaruh kebudayaan asing secara selektif. Mereka memilih hal-hal mana yang harus diterima, serta mana yang harus ditinggalkan ataupun dipadukan.

Hasil-hasil kebudayaan masyarakat Indonesia dari hasil perpaduannya dengan kebudayaan India antara lain, prasasti-prasasti bertuliskan huruf Pallawa dan bahasa Sanskerta, perpaduan kebudayaan dalam bentuk bangunan seperti candi ternyata memperlihatkan citra seni yang tinggi, dan dalam seni sastra, cerita-cerita yang berasal dari India disesuaikan dengan kondisi setempat sehingga memunculkan suatu kisah yang khas Indonesia.

Berdasarkan uraian di atas tampak jelas bahwa corak dan sifat kebudayaan Indonesia memang dipengaruhi oleh kebudayaan India, tetapi dalam perkembangannya dihasilkan lah kebudayaan Indonesia yang baru dengan corak kepribadian sendiri. Dengan keberadaan dan turut sertanya, daerah 
Kalimantan Timur dalam membangun sejarah dan manusia Indonesia kini, meninggalkan amanat yang harus diteruskan oleh generasi kini ke generasi selanjutnya. Amanat leluhur itu berupa dalam benda-benda budaya peninggalan sejarah dan purbakala. Salah satu media pelestarian pembinaan kebudayaan yang dianggap paling relevan adalah museum.

Museum sering dikatakan sebagai jendela untuk melihat sejarah kebudayaan suatu bangsa. Perumpamaan ini sangat tepat mengingat museum adalah lembaga yang bertugas melakukan pelestarian warisan budaya serta menyimpan dan merawat serta memamerkan berbagai bukti sejarah, budaya serta perkembangan alam beserta isinya. Oleh karenanya, museum telah menjadi media edukatif-kultural karena dapat menjadi sumber ilmu dan informasi dalam menunjang upaya peningkatan kecerdasan kehidupan bangsa dan perkembangan kebudayaan nasional.

Sehubungan dengan permasalahan tersebut di atas maka penulis tertarik untuk membahas bagaimana museum dijadikan sebagai sumber pembelajaran sejarah. Sebagai warga Provinsi Kalimantan Timur penulis ingin mengangkat budaya yang ada, sekaligus mengkaji lebih jauh tentang nilai-nilai peninggalan kebudayaan Hindu Buddha dan upaya pemerintah dalam melestarikan nilai-nilai peninggalan kebudayaan Hindu Buddha di Museum Mulawarman.

\section{METODE}

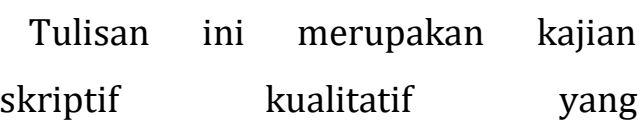
menggambarkan upaya pemerintah dalam melestarikan nilai-nilai peninggalan kebudayaan Hindu Buddha di Museum Mulawarman. Nilai-nilai peninggalan kebudayaan Hindu Buddha di Museum Mulawarman, meliputi nilai religius, nilai historis, nilai budaya, dan nilai sosial.

\section{PEMBAHASAN}

\section{Sejarah Singkat Berdirinya Museum}

\section{Mulawarman}

Sejarah singkat berdirinya museum negeri Kalimantan Timur tidak dapat dipisahkan dengan sejarah budaya Kalimantan Timur secara keseluruhan. Dengan diberlakukannya UndangUndang Nomor 17 tahun 1957 tentang penghapusan daerah swapraja dan membentuk daerah tingkat II Kutai. Pada tahun 1966 kepala kejaksaan tinggi Kalimantan Timur mengeluarkan ketentuan 01/Pem/KKTI/1966 tanggal 16 Oktober, yang menyatakan bahwa semua benda milik pribadi atau warisan dikembalikan pada pribadi, sedangkan benda milik Kerajaan menjadi milik negara. 
Dalam rangka pemeliharaan dan pelestarian semua benda peninggalan kerajaan tersebut diperlukan adanya sebuah lembaga yang tetap yaitu museum. Realisasi keinginan masyarakat serta pemerintah untuk mendirikan sebuah museum tercapai pada tanggal 25 November 1971, Pemerintah Kabupaten Daerah Tingkat II Kutai mendirikan sebuah museum yang diberi nama "Museum Kutai" merupakan bagian dari PUSKORO (Pusat Kebudayaan dan Olah Raga) yang diresmikan oleh Pangdam IX Mulawarman Brigjen Sukertiyo (sekarang Pangdam VI Tanjung Pura).

Didorong dari hal-hal tersebut di atas sebagai hasil perundingan segitiga antara Pemerintahan Daerah Tingkat I Kalimantan Timur dengan Pemerintahan Daerah Tingkat II Kutai serta DEPDIKBUD, maka pada tanggal 18 Februari 1976, museum Kutai diserahkan kepada DEPDIKBUD oleh gubernur Kalimantan Timur pada waktu itu Brigjen Abdul Wahab Syahrani yang diterima oleh Dirjen Kebudayaan Prof. Dr. Ida Bagus Mantra atas nama MENDIKBUD Republik Indonesia.

Sejak itu Museum Kutai diganti namanya menjadi Museum Negeri Provinsi Kalimantan Timur "Mulawarman" berstatus sebagai Museum Negeri Provinsi dan pengesahannya berdasarkan SK MENDIKBUD tanggal 28 Mei 1979,
Nomor : 093/0/1979 yang merupakan unit pelaksana teknis Direktorat Jendral Kebudayaan. Pemakaian nama Mulawarman untuk mengabadikan seorang raja Kutai Martadipura yang terkenal arif dan bijaksana.

Peninggalan sejarah merupakan hasil proses sejarah bangsa sepanjang masa. Benda-benda ini merupakan bukti otentik sebagai bentuk nyata dan warisan sistem nilai dan dan ide yang pernah dihayati oleh masyarakat sepanjang sejarahnya. Sebagai suatu bangsa yang sedang membangun, kita sangat memerlukan warisan tersebut, sehingga diperlukan usaha-usaha pelestarian agar peninggalan tersebut dapat diwariskan dari generasi ke generasi berikutnya. Sebagai suatu bangsa yang pernah mengalami proses sejarah dan budaya yang cukup panjang, kita cukup bangga dapat membuktikannya melalui kekayaan peninggalan sejarah, apalagi dapat dipergunakan sebagai sarana pembinaan dan pengembangan nilai-nilai luhur budaya bangsa, memupuk kepribadian bangsa, dan membina ketahanan nasional.

Museum Mulawarman merupakan objek wisata yang bermuatan ilmu dan pengetahuan yang mudah dijangkau. Museum berfungsi sebagai lembaga yang bersifat tetap, tidak mencari keuntungan, melayani masyarakat dan 
perkembangannya, terbuka untuk umum, merawat dan memamerkan peninggalanpeninggalan sejarah untuk tujuan-tujuan studi, juga mempunyai tugas menyelenggarakan pengumpulan, pengawetan, penelitian, penyajian, penerbitan hasil penelitian, dan memberikan bimbingan edukatif kultural tentang benda-benda nilai budaya dan ilmiah yang bersifat regional.

Salah satu peninggalan sejarah yang ada di Museum Mulawarman yaitu peninggalan-peninggalan kebudayaan dari masa Hindu Buddha. Pemerintah memiliki tugas yang sangat penting dalam upaya melestarikan nilai-nilai peninggalan kebudayaan Hindu Buddha di Museum Mulawarman.

\section{Koleksi dalam Ruang Pameran Tetap}

Museum Negeri Provinsi Kalimantan Timur "Mulawarman" merupakan objek wisata budaya yang bermuatan ilmu pengetahuan dan mudah dijangkau. Dari Balikpapan dapat ditempuh melalui jalur darat dengan waktu sekitar tiga jam perjalanan, sedangkan dari Samarinda dapat ditempuh melalui jalur darat dan sungai dengan waktu sekitar satu jam. Lokasi museum Mulawarman berada di tengah kota dengan penataan lingkungan yang apik dan indah yang memberi kenyamanan bagi pengunjung. Pada bagian halaman depan museum ditanam berbagai jenis pohon serta bunga dilengkapi duplikat Lembu Suana yang merupakan lambing kerajaan Kutai Kartanegara. Depan kiri dan kanan terdapat taman dengan diorama fragmen Aji Imbut serta pengawalnya mengendarai perahu, dari Dusun Pemarangan Desa Jembayan, Gresik ke Tepian Pandan (sekarang Tenggarong Kabupaten Kutai) serta kolam berbentuk naga yang merupakan lambang perjalanan hidup dan penjaga alam semesta yang telah menjadi bagian dari mitos masyarakat Kutai.

Suatu hal yang sangat menarik adalah sebuah Totem yang terbuat dari bahan kayu ulin berukuran tinggi 13 meter dengan diameter 60 centimeter. Totem ini menggambarkan perjalanan hidup masyarakat dayak dari lahir, dewasa, sampai meninggal. Ornamen yang terdapat pada bagian bawah berbentuk guci yang merupakan simbol dunia bawah (alam baka), sedangkan ular sawah melingkar dari bawah ke puncak Totem merupakan lambang kejantanan (kaum pria). Di puncak Totem terdapat ornamen burung Enggang yang merupakan lambang dunia atas.

Kompleks makam raja-raja Kutai Kartanegara berada di sebelah kanan gedung induk museum yang dilengkapi dengan penataan taman yang apik dan asri sehingga membuat para pengunjung merasa nyaman. Di belakang juga dapat disaksikan miniatur Goa Kombeng, lokasi 
ditemukannya arca prasasti Yupa, bendanya dapat dilihat dalam ruangan tetap museum (R.7 Lantai II).

Kantin dan toko souvenir berada di belakang museum. Sedangkan kompleks makam dan arsitektur tradisional Suku Dayak yang ada di Kutai, antara lain berupa bangunan Bleh Peteh yaitu wadah untuk kalangan Suku Dayak Kenyah, patung-patung Blontang yang berfungsi sebagai peralatan upacara adat kematian Suku Dayak dan beberapa bentuk lungun yang semuanya ditata secara evokatif. Di samping itu, terdapat patung dalam bentuk ular lembuh (istilah Kutai), pesut dan buaya, patung ini memperindah lingkungan museum agar para pengunjung memperoleh kesan yang menarik dan berkeinginan untuk berkunjung lagi. Untuk masuk ruangan tetap, kita melewati pintu utama pada bagian depan dengan anak tangga pada bagian kiri dan kanan tangga terdapat area patung harimau/macan sebagai penjaga keamanan.

\section{Nilai-Nilai Peninggalan Kebudayaan Hindu Buddha di Museum Mulawarman}

\section{Nilai Religius}

Menurut Soekanto Soejono (1983: 229) religi merupakan seperangkat kepercayaan dan praktek spiritual yang dianggap sebagai tujuan tersendiri. Nilai religi dan upacara keagamaan merupakan produk manusia sebagai homoreligius. Manusia yang mempunyai kecerdasan, pikiran, dan perasaan luhur, tanggapan bahwa kekuatan lain maha besar yang dapat "menghitam-putihkan" kehidupan.

Nilai religius peninggalan kebudayaan Hindu Buddha yaitu adanya peninggalan-peninggalan berupa arcaarca Hindu Buddha, arca dewa yang dipamerkan di Museum Mulawarman merupakan arca dewa-dewa utama dari Agama Hindu dan Buddha, dengan adanya arca-arca tersebut dapat kita ketahui bahwa pada satu masa pernah berkembang Agama Hindu dan Buddha di Kalimantan Timur.

Nilai-nilai religius yang masih ada pengaruh Agama Hindu dan Buddha yaitu adanya upacara kematian yang sudah dimodifikasi, tata caranya masih sama seperti pada masa Hindu Buddha tetapi bacaan yang dipakai sekarang yaitu bacaan dalam ajaran Islam seperti yasin dan tahlil, karena masyarakat yang menjalankannya sudah menganut Agama Islam. Kalau hari upacara kematiaannya masih tetap yaitu 1,2,3,7,21, dan 40 hari setelah kematian.

\section{Nilai Historis}

Istilah-istilah sejarah dalam bahasa barat seperti halnya history dalam bahasa Inggris, histoire dalam bahasa Prancis, historia dalam bahasa Latin yang bersumber dari bahasa Yunani historein lebih menunjuk pengertian yang 
mengarah kepada konsep ilmu. Menurut Plato (Daliman, 2012 : 03) "historein atau historia berarti penyelidikan atau pengetahuan". Berdasarkan penjelasan di atas dapat diketahui bahwa nilai historis adalan nilai sejarah. Nilai historis peninggalan kebudayaan Hindu Buddha di Museum Mulawarman yaitu ditemukannya tujuh buah Prasasti Yupa di Bukit Brubus, Kecamatan Muara Kaman, Kabupaten Kutai Kartanegara. Ke-7 prasasti ini menandakan dimulainya zaman sejarah di Indonesia, karena prasasti ini merupakan bukti sejarah tertulis pertama yang pernah ditemukan. Berdasarkan perbandingan tulisan, prasasti ini diperkirakan berasal dari abad IV Masehi.

\section{Nilai Budaya}

Menurut Koentjaraningrat (1981 : 5) wujud kebudayaan adalah ideal. Wujud ideal kebudayaan adalah sebagai salah satu kompleks dari ide-ide, gagasangagasan, nilai-nilai, norma-norma, peraturan-peraturan dan sebagainya. Nilai budaya peninggalan kebudayaan Hindu Buddha dapat kita lihat pada pelaksanaan upacara-upacara adat. Pada zaman dahulu, upacara-upacara adat dilaksanakan dengan tujuan untuk melindungi raja-raja dari segala bahaya. Salah satu contoh upacara adat yang masih mendapat pengaruh Hindu Buddha adalah upacara adat Erau. Pada pelaksanaan upacara Erau peralatan- peralatan yang digunakan sampai dengan tata cara pelaksanaannya masih dipengaruhi oleh Hindu Buddha. Upacara adat Erau pertama kali dilaksanakan pada upacara tijak tanah dan mandi ke tepian ketika Aji Batara Agung Dewa Sakti berusia lima tahun, dalam perkembangannya upacara Erau dilaksanakan untuk upacara penobatan raja dan pemberian gelar dari raja kepada tokoh atau pemuka masyarakat yang dianggap berjasa terhadap kerajaan.

Nilai Sosial

Menurut Kamus Besar Bahasa Indonesia (2006 : 502) sosial adalah sifat suka memperhatikan kepentingan umum. Nilai sosial peninggalan kebudayaan Hindu Buddha yaitu nilai sedekah, nilai gotong-royong, nilai tolong-menolong, nilai musyawarah, serta adanya interaksi sosial yang baik antara pemerintah dan masyarakat dalam mempersiapkan segala sesuatu yang dibutuhkan untuk pelaksanaan upacara Erau.

\section{Upaya Pemerintah dalam Melestarikan Nilai-Nilai Peninggalan Kebudayaan Hindu Buddha di Museum Mulawarman}

Upaya pemerintah dalam melestarikan nilai-nilai peninggalan kebudayaan Hindu Buddha di Museum Mulawarman terbagi menjadi tiga yaitu menjaga, merawat, dan menaati peraturan. Dalam menjalankan tugas 
tersebut, pemerintah berpegang teguh pada Undang-Undang Nomor 11 Tahun 2010 Tentang Cagar Budaya dan UndangUndang Nomor 10 Tahun 2009 Tentang Kepariwisataan.

Upaya yang dilakukan pemerintah dalam melestarikan nilai-nilai peninggalan kebudayaan Hindu Buddha di Museum Mulawarman, yaitu perlindungan, perawatan dan penaatan peraturan.

\section{Perlindungan}

Dalam menjaga nilai-nilai peninggalan kebudayaan Hindu Buddha yang terdapat di Museum Mulawarman, pemerintah melakukan tugas fungsinya pengamanan, pengembangan (melaksanakan penelitian, revitalisasi, dan adaptasi), pemanfaatan (dalam bidang agama, pendidikan, sosial budaya, dan pariwisata), pemeliharaan (dilakukan oleh juru pelihara), dan yang terakhir yaitu pemugaran.

\section{Perawatan}

Dalam merawat peninggalan kebudayaan Hindu Buddha di Museum Mulawarman yang bersifat benda ditugaskan kepada beberapa juru pelihara yang telah mendapatkan pembinaan tentang tata cara perawatannya, sedangkan bila sifat peninggalannya bukan benda, melainkan berupa nilai-nilai budaya, maka pemerintah akan mengadakan berbagai even budaya seperti festival budaya dan mengadakan upacara-upacara adat setiap tahunnya.

\section{Menaati Peraturan}

Upaya pemerintah dalam menaati peraturan yaitu dengan berpegang teguh pada Undang-Undang Cagar Budaya Nomor 11 tahun 2010 dan UndangUndang Kepariwisataan Nomor 10 tahun 2009, mensosialisasikan peraturan, dan mengikuti pelatihan-pelatihan tentang perawatan koleksi-koleksi museum.

\section{PENUTUP}

Nilai-nilai peninggalan kebudayaan Hindu Buddha di Museum Mulawarman antara lain nilai religius, nilai historis, nilai budaya, dan nilai sosial. Nilai religius yaitu adanya peninggalanpeninggalan berupa arca-arca Hindu Buddha.

Nilai historis yaitu ditemukannya tujuh buah Prasasti Yupa di Bukit Brubus, Kecamatan Muara Kaman, Kabupaten Kutai Kartanegara, hal ini menandakan dimulainya zaman sejarah di Indonesia, karena prasasti ini merupakan bukti sejarah tertulis pertama yang pernah ditemukan. Nilai budaya dapat kita lihat pada pelaksanaan upacara-upacara adat, salah satu contohnya yaitu pada pelaksanaan upacara Erau, peralatanperalatan yang digunakan sampai dengan tata cara pelaksanaannya masih dipengaruhi oleh Hindu Buddha. Nilai sosial yaitu nilai sedekah, nilai gotong- 
royong, nilai tolong-menolong, nilai musyawarah, serta adanya interaksi sosial yang baik antara pemerintah dan masyarakat.

Upaya pemerintah dalam melestarikan nilai-nilai peninggalan kebudayaan Hindu Buddha di Museum Mulawarman yaitu menjaga, merawat, dan menaati peraturan. Dalam merawat peninggalan kebudayaan Hindu Buddha di Museum Mulawarman yang bersifat benda ditugaskan kepada beberapa juru pelihara yang telah mendapatkan pembinaan tentang tata cara perawatannya, sedangkan bila sifat peninggalannya berupa nilai-nilai budaya, maka pemerintah akan mengadakan even budaya setiap tahunnya. Upaya pemerintah dalam menaati peraturan yaitu dengan berpegang teguh pada Undang-Undang Cagar Budaya Nomor 11 tahun 2010 dan Undang-Undang Kepariwisataan Nomor 10 tahun 2009, mensosialisasikan peraturan, dan mengikuti pelatihan-pelatihan tentang perawatan koleksi-koleksi museum.

\section{REFERENSI}

Bupati Kutai Kartanegara. 2001. Membangun Kembali Kebanggaan Budaya Keraton Kutai Kartanegara. Kutai Kartanegara: Lembaga Ilmu Pengetahuan Kutai Kartanegara.

Central Java. 2009. Undang-Undang Nomor 10 Tahun 2009 Tentang Kepariwisataan.http://www.central- java-tourism.com, (dialses pada 02 Desember 2015)

Daliman, A. 2012. Metode Penelitian Sejarah. Yogyakarta: Penerbit Ombak.

Hukum Online. 2014. Undang-Undang Nomor 11 tahun 2010 Tentang Cagar Budaya. http://www. hukumonline.com (diakses pada 02 Desember 2015)

Koetjaraningrat. 1981. Pengantar Ilmu Antropologi. Jakarta : Rineka Cipta.

Soekanto, S. 1983. Teori Sosiologi Tentang Perubahan Sosial. Jakarta : Ghalia Indonesia. 